insect is doing a great deal of damage. I believe that in many cases in the past in such investigations we have discontinued the work just at the time when we should have continued it. That is almost a typical example of what I just mentioned.

There appears next on the program, "Notes on the Biology of the Angoumois Grain Moth," by Mr. King, of Harrisburg, Pa.

\title{
NOTES ON THE BIOLOGY OF THE ANGOUMOIS GRÄIN MOTH, SITOTROGA CEREALELLA OLIV.
}

\section{By J. L. KING, ${ }^{1}$ Scientific Assistant, Bureau of Economic Zoology, Harrisburg, Pa.}

In recent years the southeastern wheat producing counties of Pennsylvania have suffered an aggregate annual loss of over a million dollars through the yearly pillage of the wheat crop by the Angoumois grain moth (Fig. 5). Most of this loss occurs after harvest, and is due to the common practice in this region of storing unthreshed grain in the barns until some convenient time for threshing, then too, it is interesting to note that the Angoumois grain moth does not confine its depredations entirely to stored grain, as hitherto considered, but may begin its attack on the developing grain in the field, as is shown in the following study of the life-history.

\section{Life-History of the Angoumois Grain Moth}

On May 1, 1917, a field station was located at York in York County, Pa., for this study. Observations started immediately in a series of field investigations, and inspections of straw stacks, barns, granaries, mills and warehouses.

Hibernating Larva.-In the fields no evidence of hibernating larvæ could be found, nor did surrounding conditions appear favorable for them. On the other hand, mills and warehouses contained much infested wheat, but these were generally confined to the towns and cities. On the farms in the infested districts little or no wheat remained. However, in practically all the supposedly empty barns infested grain was found lodged in the cracks and crevices of the mow floor, on the beams above the mow, or under straw piles: and not infrequently hay, which had been partly covered by the sheaves of wheat, contained infested grain which had been shaken from the heads. In a number of instances large bags of mill screening were found to be literally "pure cultures" of living Angoumois larvæ.

1 The writer takes pleasure in expressing his appreciation of the kind suggestions of Prof. J. G. Sanders, under whose direction these studies were conducted. 
The larvæ pass the winter within this scattered grain in various stages of development between the half-grown and mature larval stages. In the early spring the immature larvæ again start to feed and complete their growth; the fully grown larvæ remain quiescent until shortly before the pupation period.

The Cocoon.-During the middle and latter half of May the larvæ start to spin their delicate silken cocoons within the wheat grains. The space thus occupied by the cocoon is cleared of all frass particles, this generally being packed to one side of the hollow grain, or sometimes it is cast out of the grain through a small hole which is gnawed through the side. Further preparation for final exit is made by gnawing almost through the distal end of the grain (the end opposite the plumule), leaving only a very thin circular membrane. The cocoon proper is thin and delicate, consisting of but a single layer of fine white silk which covers the walls of the cavity. After spinning the cocoon the larvæ remain quiescent for two to three days before pupation occurs.

Pupation.-At York, Pa., pupæ were found as early as May 10, but were not abundant until after May 20.

The duration of the pupal period as observed at York during late May and early June varied from ten to seventeen days, having an average of thirteen days. When first formed the pupæ are light honey yellow, but soon turn to a golden brown as they harden. Before the final ecdysis takes place the developing moth is easily seen through the transparent pupal sheath.

Emergence and Habits of the Moths.-The moths emerged throughout the day, but seemingly a larger per cent leave their cocoons during the morning. Escape from the cocoon is made by pushing against the thin exit membrane, which parts at the margin, and lifts as a hinged lid. The expansion of the wings is accomplished in fifteen to twenty minutes, and feeble flight is possible within an hour after emergence, but as a rule flight does not take place for several hours.

The moths are crepuscular in habit, being most active in the dusk of early evening and morning. At these times they may be observed mating and depositing their eggs.

The moths which develop from the hibernating larvæ constitute the first brood, or spring generation, which causes the initial larval damage to the season's wheat crop. This brood appears toward the end of May, and seems to reach its maximum numbers between June 5 and 15. After June 20, moths are not common.

Oviposition.-As the period of oviposition is indicated by the period of the moth flight, it is worthy of note that this is also coincident with the heading of the wheat in the fields. In York, Pa., and the 
surrounding country much of the wheat is in head as early as June 1, but bloom does not follow until about the 4th, continuing over varied conditions until about the 15th. However, most of the grain is well set before this latter date.

At this time a large series of experiments were conducted to determine if the adults would oviposit on green wheat, and what stages in the growth of the grain would be necessary for the sustenance and development of the newly hatched larvæ; also, to determine if oviposition naturally occurred in the field upon the green heads. Single female moths, accompanied with two or three males, were confined in small tarlatan bags, and placed over the heads of growing wheat, which was in varying stages of growth-from pre-bloom to well-set, milky grain.

In all but three cases out of forty the moths so confined deposited their eggs upon the heads of green wheat. The eggs were commonly found carefully inserted under the protecting outer and empty glumes; also, along the edge of the glumes covering the seed. However, this placement of the eggs is not unerring, as eggs are sometimes placed between the spikelets and the main stalk.

The eggs are sometimes deposited singly, but clusters of four to sixteen are not uncommon. The total number of fertile eggs per individual ranged from thirty-six to one hundred and forty-six. The average total egg production in the case of four moths under observation was ninety-two, in which case 44 per cent were deposited the first day (24 hours) after mating, and 19 per cent the second day. Later egg production decreased suddenly, falling to 3 per cent on the fourth day. Under the warm temperature of mid June, the egg stage lasts from seven to nine days. Moths in tarlatan bags in the field lived three to eight days, having an average longevity of five and twofifths days, whereas those protected from the rigors of the weather lived an average of seven days.

Habits of The First Stage Larva.-Wheat in all stages of development, from the incipient seed before pollination to the green grain, in the milk is subject to the attacks of the larvæ. However, in nature few larvæ appear early enough to attack the heads before pollination.

The larvæ after leaving the eggs immediately distribute themselves over the head on which the eggs had been deposited, and almost invariably but a single larva enters each grain. The larvæ enter the grain by gnawing through the soft pericarp, either near the proximal or distal end of the grain, or through the longitudinal furrow. At first larval growth seems slow, and only slightly impedes the growth of the grain, but ultimately, as the larvæ become mature, the entire wheat grain is hollowed out.

Length of Life Cycle.-Larvæ which entered wheat while in 
bloom June 13 began to emerge as adults on July 23, continuing to July 31 ; thus requiring from forty-one to forty-nine days from hatching of larvæ to emergence of the moths. Likewise, larvæ that entered green and milky wheat required from forty to fifty-four days to complete their development.

Inasmuch as the Angoumois grain moth has been considered an economic pest of stored grain, it seems worthy of note that the foregoing observations on oviposition and development of larvæ within unripe grain were also verified by coinciding field observations. Eggs and young larvæ were found in the growing grain during early June, and adults began to emerge in late July from the harvested grain,

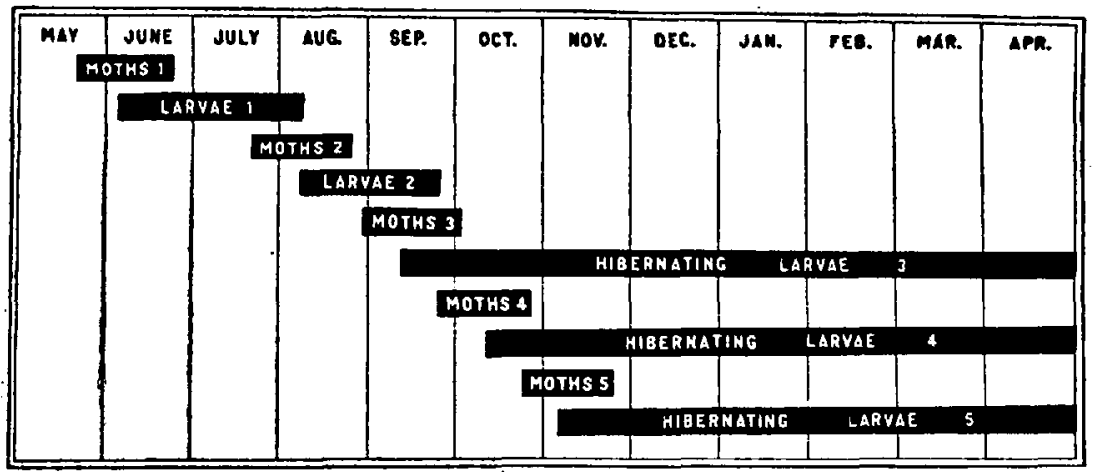

Fig. 4. Diagram of broods of Angoumois grain moth. Moths 1, first brood from overwintering larvæ in barns and granaries; Larvæ 1, larvæ in developing grain; Moths 2, second brood at harvest time; Larvæ 2, second brood larvæ occurring in feld or stored grain; Moths 3, third brood in stored grain, and in part in waste grain in field; Hibernating larvæ 3, part transforms to fourth brood-remainder hibernate; Moths 4, fourth brood; Hibernating larvæ 4,-part forms fifth broodremainder hibernate; Moths 5, fifth brood; Hibernating larvæ 5, fifth brood larva all hibernate.

coincident with moths reared in the experiment plots. This initial field infestation is sparse and scattered, thus accounting for the very general distribution of later broods.

Number of Generations.-The moths appearing at harvest time constitute the second generation, which occurs approximately between July 20 and August 14, with its maximum numbers during August 1 to 6 . In case of late gathering-in of the harvest a small part of this brood emerge as moths in the fields, which in turn gives rise to a third brood during September 1 to September 20. This third brood is the final brood occurring in the field. On the other hand, the moths of the second generation, which emerge in the warm tight barns, carry on their depredations through as many as six, and possibly seven, genera- 
tions-providing the grain remains unthreshed in the mow and severe cold weather is delayed.

\section{Farm Practice Favorable for the Moth}

A common farm practice in the region under consideration is to store the unthreshed wheat in the mow until some future time when threshing is convenient, or to thresh the grain only as there is need for the straw. This method of storing grain in the exceptionally tight and well-built barns, which are characteristic of this region inhabited by Pennsylvania Dutch, is conducive to a most rapid development of the moths. During the month of August, wheat in the mow of one of these

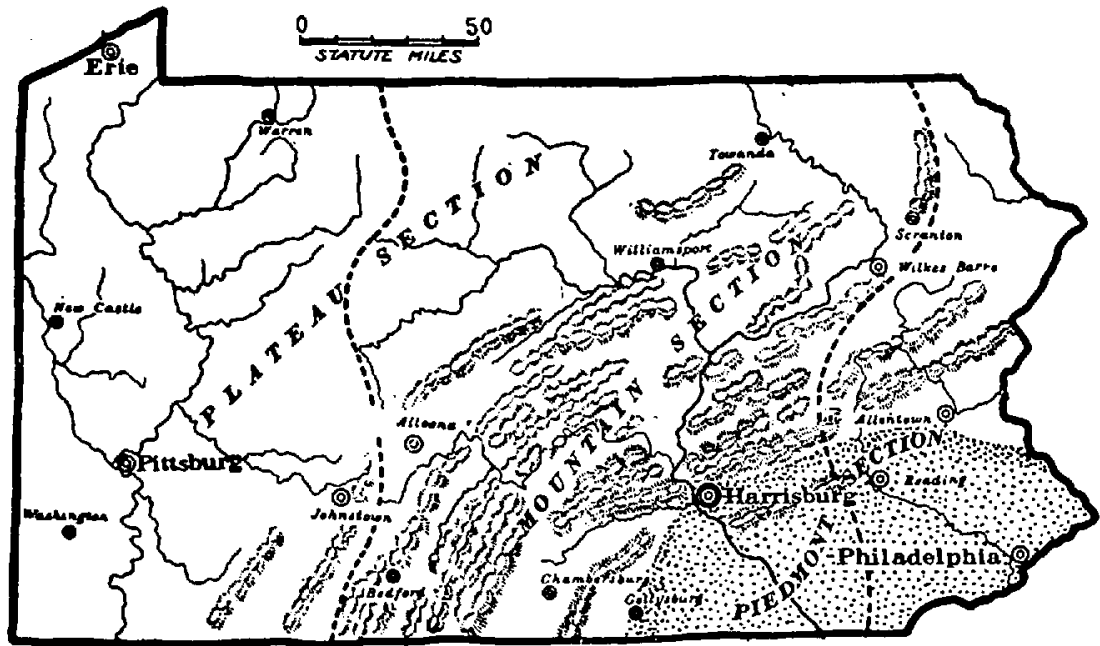

Fig. 5. Map of Pennsylvania with shaded area showing region of severe Angoumois infestation.

infested barns retained an almost constant temperature of eighty to eighty-five degrees F., and during September a temperature of seventy to seventy-five degrees F. This so stimulated growth that by the end of October as many as five generations had been reared (Fig. 4).

\section{Control Measures}

The greatest step in the control of this pest will be accomplished as soon as the Pennsylvania farmers see the fallacy of storing unthreshed grain for long periods in the mow, and will thresh as soon after harvest as possible. Grain stored in tight granaries, or in good sacks, is less liable to repeated attacks of the moth, and may be easily treated with carbon bisulphid. Further, attention to thorough barn sanitation, by the elimination or complete utilization of all scattered wheat, is of 
extreme importance in checking this pest. Thorough sweeping of the mow floor and beams is necessary. Poultry enclosed in the barn will also aid in cleaning the grain from the cracks and crevices of the floor. Infested screenings if kept in the barn should be ground, or immediately used as feed, and in the future all grain should be threshed in the open to avoid reinfestation of the barn.

Finally, all sanitary work should be of a coöperative nature throughout an infested district, in order to insure against reinfestation from a negligent neighbor. Under the present conditions it is not advisable to do away with carbon bisulphid fumigation, but the writer is of the opinion, that in the future if coöperative early threshing and thorough barn sanitation are practiced, the use of carbon bisulphid will not be necessary.

President R. A. Cooley: Do you wish to discuss the paper by Mr. King on this grain pest?

Mr. J. G. SAnders: These five counties in southeastern Pennsylvania produced probably one third of the entire wheat output of the state. I think the latest figures are approximately $13,000,000$ bushels. The loss in some sections last year and the year before ran as high as 75 to 90 per cent of the crop in some limited areas.

I do not think Mr. King brought out very vividly or strongly the reason why this pest seems to cause such great destruction in this area: because in this area the farmers have that unfortunate habit of storing their cut or harvested grain in the mows and then threshing it out during the winter as they need the straw, or as occasion affords. The problem of saving anywhere from one to two or three million bushels of wheat at this time is extremely important, and if we can secure the coöperation of farmers in that section of the state next spring to carry on sanitation measures in cleaning up the old hang-over wheat in every conceivable place and position, I think we would be accomplishing a very desirable result.

Ultimately, I think that the pest can be held in control by sanitation measures, without resorting to fumigation with carbon bisulfid. That is only ameliorating the condition at best; but if we can secure the coöperation of the farmers and if they will change their habits of farming, I think this pest will disappear. It is one of the most serious pests, as we now realize.

Mr. M. H. Swenk: I am interested in this because during the past summer for the first time we found this insect working in the wheat fields in Nebraska. I want to ask Mr. King definitely if he has any indications in his studies of the life-history, that it is possible for the angoumois grain moth to persist in the field throughout the year, or must it always emanate from granaries individually? 
Mr. J. L. KING: This study has only been conducted since the first of May. I have found larvæ hibernating in the field. I am studying them under various conditions and I have also planted infested grain, through which there seems to be some possibility that they might be carried into the soil. At first I didn't think it was at all possible, but I was greatly surprised on planting infested grain to have a few moths work their way up through the soil and they could fly away. Whether larvæ can go through the winter, I am unable to state as yet.

Mr. G. A. Dean: For at least ten years the grain moth has been one of the most serious pests we have had in Kansas in several different grains. It was first very serious in wheat, laying its eggs in the chaff and also in the stem. Now they are not causing much trouble to the wheat because the farmers thresh as soon as they can after harvesting; but it has gone into the chaff. The grain moth in Kansas is the most serious pest we have in those seeds, when stored. Our farmers must fumigate these seeds with carbon bisulfid before they are sowed. If they don't they will lose from 50 to 75 per cent of them. Our seed men had that sad experience with the angoumois moth.

President R. A. Cooley: The meeting will now stand adjourned. Adjournment.

Morning Session, Tuesday, January 1, 1918, 10.00a.m.

President R. A. Cooley: The first paper on the program is by E. P. Felt on "Insects and Camp Sanitation."

\section{INSECTS AND CAMP SANITATION}

By E. P. FELT, State Entomologist of New York

The battlefields of Europe are now the assembly grounds for the human race. Some of almost all nationalities and huge numbers of a few have met in a struggle of world-wide significance. They have brought with them their blood parasites and infections and all too frequently carriers of disease. We know that lice and typhus, flies and cholera, typhoid and dysentery, fleas and bubonic plague, mosquitoes and malaria, are to be found among the troops of the battle-scarred regions.

Here is a biological complex or association unparalleled in the history of the world and the complexity is still increasing. The dispersion at Babel is being followed by the assembly at Armageddon. Other nations are entering the conflict and at present many thousands and soon millions of American citizens may be directly involved in this gigantic struggle. We are more deeply concerned with these last, though it should not be forgotten that our future is closely linked with that of our 
Allies and, moreover, that undue prevalence of disease among the enemy may, though giving us temporary advantage, ultimately react to our hurt. It should be remembered that while the problems of the war may be most urgent and vital, those that follow may be even more serious in their effects on the human race. Earlier conflicts have been followed by epidemics of disease, some extremely disastrous, and there is no reason for believing that the same will not obtain in at least some measure as an outcome of this struggle.

Susceptibility to disease is a most important factor and it is to be feared that in this respect American troops will be at a disadvantage, as compared, at least, with certain other combatants, owing to the fact that our higher standards of living have in a measure reduced resistance to disease, though this may be offset to some extent by preventive inoculations.

The importance of disease control under army conditions is not generally appreciated, though it is a well-known fact that in the Spanish War, a disturbance accompanied by very little fighting on the part of Americans, deaths from disease greatly exceeded those from wounds. The total number of deaths among the British non-commissioned officers and men in the Crimean War from April, 1854 to June, 1856 was 18,058 , including all who died in the field or in the hospital from wounds and disease. Deducting 1,761 deaths from wounds, we have 16,297 deaths from disease. ${ }^{1}$ In the South African War, 1899 to 1902, 6,965 died from wounds, as compared with at least 13,590 from disease, while 72,551 sick were invalided back to England. It is significant to note that for every man admitted to a hospital on account of wounds, 17 were admitted because of disease. ${ }^{2}$ In 1869 there were 972 deaths from cholera among the British soldiers in India, while in 1912, with a much larger number, there were only $14 .^{3}$ The importance of affections of the digestive tract is shown by the fact that the chief epidemic diseases of the Mediterranean Expeditionary Force were enteric (typhoid) fever and dysentery. During the last six months of 1915 there were admitted in General Hospital 21 on the medical side 5,300 cases, 1,723 being classed as enteric and 1,146 as dysentery; thus more than half the medical cases came in one of these two classes." Cholera was quite prevalent in Austria-Hungary, especially Galicia, from September 27, 1914 to September 18, 1915, there being 27,591 cases with 15,270 deaths. ${ }^{5}$

1 1917. Garrison, F. H. Military Surgeon, 41: 469-470.

21917. Copeman, S. M. Journal of State Medicine, 25: 105.

1917. Goodwin, T. H. Military Surgeon, 41: 386.

1917. Bartlett, G. B. Quarterly Journal of Medicine, 10: 186.

1917. Ford, J. H. Military Surgeon, 41: 7. 
The above figures give an idea of the great importance of disease from a military standpoint. It will be noted that the number of deaths in hospitals from disease exceeds and in certain cases greatly exceeds, the number of deaths from wounds. This by no means tells the whole story, since in Serbia during the winter of 1914-1915 there was a general outbreak of typhus, one in every five of the population developing the disease and 135,000 (including 30,000 Austrian prisoners) dying. The mortality ranged as high as 65 per cent though in some hospitals it was as low as 19 per cent. ${ }^{1}$

The results possible from the application of preventive measures is indicated by the following: During the first winter of the Crimean War the British had 2,286 deaths from fever and 129 in the second. They lost 164 men from typhus the first winter and but 16 the second. There were 3,196 deaths of British soldiers during the first winter from diarrhoal disorders and only 37 in the second winter. ${ }^{2}$ During the first twelve months of the present war the average monthly mortality rate for disease was, in round numbers, 29 per thousand and for the succeeding eight months 14 per thousand, while for wounds the rate was 34 per thousand for the first year and 15 per thousand for the first eight months of the second year. ${ }^{3}$

The foregoing data has been restricted by design largely to diseases which are carried in part or entirely by the agency of insects, since this paper is primarily entomological. In not a few instances the control of disease is determined by the solution of the insect problem and this is notably true of typhus and lice, bubonic plague and fleas and mosquitoes, yellow fever and malaria. The intimate relation between insects and disease is less evident though very real in the case of fies and such affections as cholera, typhoid, dysentery and probably tuberculosis. We know that insects may be carriers of all these diseases and it has become evident within the last few months that the hardships and privations of war have been followed by numerous cases of tuberculosis and it is reasonable to expect, even if there be no epidemic, that other preventable diseases will exact a heavy toll among the unfortunate populations of the stricken areas. The situation, in our estimation, justifies the ranking of the insect menace as one of the important problems in the conduct of the war, second only to the equipment and provisioning of the army and the adequate care of the sick and wounded. In fact, insect control is intimately connected with the last. Not only is there urgent need of looking after this phase of sanitation but the probabilities are, as the war progresses, that the medical

1 1916. Beasley, S. O. Military Surgeon, 39: 634.

3 1917. Garrison, F. H. Military Surgeon, 41: 469-470.

1917. Military Surgeon, 40: 100. 
and sanitary stafis will be so overwhelmed with the care and protection of the seriously stricken, that matters of apparently minor importance, such as the control of insect pests, must of necessity be neglected to some extent. As indicating probabilities along this line a note credited to Lord Northcliffe is worthy of reproduction: "It is well known now that in spite of the almost universal efficiency which characterized German preparation for the war, the German medical force dropped down entirely and was unable to meet the terrific casualties." Both knowledge and reason indicate that prevention is far more effective than cure. Here is where the entomologist should step in and relieve the physician and sanitarian by discharging a duty for which he is particularly qualified. It is gratifying to note in this connection that in the "British Army every expeditionary sanitation unit of seventy men, rank and file, now includes two trained entomologists."' American efficiency may accomplish much, though it is hardly believable that in a few short months we can handle matters as satisfactorily in all details as a nation which has spent years in preparing for just such eventualities and for that reason, if for no other, we should take advantage of every supplemental agency.

Insect control under field and camp conditions presents many problems which cannot be foreseen. It can be handled best only by those who have had extensive experience with insects and are therefore in the position of experts so far as determining what methods should be adopted for either normal or emergency conditions. It is well known that work under the guidance of men who appreciate the possibilities is likely to be vastly more successful than that supervised by those unacquainted through experience with the problems they are expected to handle. Every economic entomologist has been the recipient of hundreds of accounts of failure to control insects, and in practically every case this has been due to not grasping the essentials though an honest endeavor may have been made to carry out directions. We submit that in cases where human life, in many instances thousands of lives are imperiled, the best is none too good and, if there be failure, the employment of experts would presuppose that every reasonable precaution had been adopted.

The work should be organized on a unit basis and a competent entomologist attached to every large military unit and accorded a ranking which will insure respect for his recommendations. There would naturally be several main lines of effort, viz.:

1. Protection against disease carriers. This would resolve itself first into the elimination, so far as practical, of opportunities for insects

1 1917. Military Surgeon, 4: 31.

2 1917. Calvert, P. P. Old Penn, 15: 302. 
to become infected, a phase which largely devolves upon the physician, though the entomologist might render conspicuous service. It would fall to the latter to see that every reasonable precaution was adopted, to reduce the breeding of insects to a minimum and to check their dissemination so far as possible. The last is of special importance with body parasites.

2. The protection of food, though vastly less important than the preceding, should receive attention, since by the adoption of comparatively simple precautions in handling and storage it would be possible to avoid waste and serious loss. Inspection by an entomologist would in most cases determine the probable source of infestation and go far toward fixing responsibility.

3. Protection of domestic animals. A general survey of camp surroundings would indicate at once the more prolific breeding places for mosquitoes, especially malarial carriers, and would incidentally disclose the localities most likely to be infested by horse flies and similar troublesome pests. The location of the camp and the disposition of camp refuse, including the manure from animals, must be determined largely by local conditions and apparently unimportant modifications may have a material effect upon the abundance of insects and the annoyance and danger resulting therefrom.

It is not expected that a flyless and insectless camp can be maintained, especially under field conditions, but it is practical, by the adoption of systematic measures, to largely reduce the insect menace, not only by the prevention of breeding but by the adoption of special means of protection wherever there is an opportunity for the dissemination of disease. The autocratic military type of organization is admirably adapted to the carrying out of such work. This latter, as has been pointed out earlier, is of particular importance in the case of American troops because they are presumably more susceptible to certain infections than men who have lived for years under less sanitary conditions.

With the above in mind, we hold that the entomologist, particularly the economic entomologist, is in a position to render invaluable service in protecting the health of our troops and that, furthermore, the efficiency of the sanitary and medical corps of the army will be greatly increased by the coöperation of such experts, since their special knowledge would permit the quick solution of many difficult problems and at the same time relieve our medical men for their very necessary and frequently more urgent duties.

There is another phase of the problem which should ever be kept in mind and that is conditions likely to obtain after the war. Almost every great war has been followed by widespread, frequently very 
deadly epidemics, not only in sections directly affected but also in other parts of the world, especially those to which combatants returned. The world-wide character of this conflict makes the latter phase of great importance to all nations, since the removal of military restrictions, unless there be a rigid sanitary supervision, would give unexampled opportunities for carriers of deadly infections to make their way into other countries and spread disease. This applies to insect borne infections as well as to other maladies. Only the most thorough precautions can prevent extensive outbreaks and certain safeguards are not possible unless there is an intimate and general knowledge of the habits of insects serving as carriers.

The heavy hand of poverty is destined to rest upon extensive areas of the earth and with that may be expected a lowering of sanitary standards and a consequent increase in disease. It is most important that this latter be prevented so far as possible so that post-war conditions may not be worse than those at present obtaining. This can be accomplished by the adoption of the most effective methods for the control of disease and here the entomologist is in position to render an exceedingly valuable service not only to his country but to the entire world.

The vital importance of the effective control of disease is indicated by the following excerpts from the introduction to "Epidemics Resulting from Wars."'

An examination of the facts presented in the monograph "indicates that until comparatively recent times the most serious human cost of war has been not losses in the field, nor even the losses from disease in the armies, but the losses from epidemics disseminated among the civil populations. It was the war epidemics and their sequele, rather than direct military losses, that accounted for the deep prostration of Germany after the Thirty Years' War. Such epidemics were also the gravest consequence of the Napoleonic Wars. . . . One can point to the fact that in the present great war, the only serious epidemic that has been reported is the typhus fever epidemic in Serbia. When the medical history of the war comes to be written, however, it will be found that the aggregate losses from sporadic outbreaks of war epidemics have been very considerable. A war sufficiently protracted to lead to universal impoverishment and a breakdown of medicalorganization would be attended, as in earlier times, by the whole series of devastating war epidemics. And even in the case of less exhausting wars, the chances of widespread epidemics are far from negligible."

\footnotetext{
${ }^{1}$ Epidemics Resulting from Wars, by Dr. Friedrich Prinzing, published by the Carnegie Endowment for International Peace, Division of Economics and History, John Bates Clark, Director, p. VIII-IX, 1916.
} 
Large portions of the world are already in the condition described in the last sentence and considerable areas have suffered so greatly that general impoverishment is almost unavoidable and as the war continues larger areas, possibly territories inhabited by several nations, will be reduced to this pitiable condition.

Summary.-Diseases are responsible for more deaths in armies during war time than are caused by wounds.

Insects are known carriers of some of the most deadly infections of the soldicr and the only known means of dissemination for certain of these diseases.

Available data appear to justify the opinion that over one half of all the deaths in armies due to disease are caused by infections easily and frequently carried by insects, and some only through insect agencies.

Proventive inoculation has largely eliminated the danger from typhoid fever, though it is of no value against the nearly equally deadly dysentery. The insect menace is therefore, judged from both a military and economic standpoint, most serious and its reduction to the lowest possible terms is abundantly justified. This is not only important during war time but doubly necessary at and just after the conclusion of peace.

The military history of the world abounds with appalling examples of disastcr following the appearance and rapid spread of insect-borne epidcmics, one such already being known in connection with the present conflict.

The experience of our adversaries in this struggle has demonstrated that there cannot be too great preparation along medical and sanitary lines, while our allies have been forced by developments to make use of available entomological talent.

It is well known that camp conditions are favorable to the development of insects and, moreover, that these pests may thrive under very diverse conditions and gain access to deadly infections in most unexpected places.

The satisfactory control of such pests requires expert knowledge based upon arduous training and extensive experience and consequently we believe that the entomologist, the man with practical experience in the control of insect outbreaks, is in position to render invaluable service in protecting the health of our troops and at the same time relieving to a certain extent members of the sanitary and medical corps for their very important and frequently most pressing duties.

President R. A. Cooley: We have had presented to us a very valuable contribution on this important subject. I will now ask you to discuss this paper. 
Mr. J. L. KING: I think every entomologist is especially interested in the present war and is willing to give his service in any branch which will be of aid to his country. After arriving in Pennsylvania, I found that the young men in the house where I was staying had enlisted in various branches of the military service which were along the lines of their particular training, and I therefore decided to make application. I wrote to Dr. Howard in order to find out whether there was any opportunity for service in the army along entomological lines. As there did not appear to be any opcnings, I made application in the sanitary service, but was informed that there were no openings there. What I would like to ask is, How are the services of the entomologists to be utilized in connection with camp sanitation? "It secms almost impossible to enter the service at the present time.

Mr. E. D. BaLL: I would like to ask Dr. Felt whether there has been any movement made in this direction.

Mr. E. P. FeLt: At the time when it began to be apparent that the United States might be involved in the war, the speaker wrote one or two editorials in favor of having an entomologist attached to every large army unit and he is still of the opinion that such is highly advisable. It may be true that our economic entomologists are largely trained in handling agricultural insects, but I think every man who has had any experience whatsocver on insect work would be willing to back such a man against one who has not had such experience. That is his life work and with his intimate knowledge of insects, he is placed in a far better position than anyone else to forecast possibilities, to see the danger points and to adapt treatment to the conditions. I am of the opinion that there must be a great amount of this kind of work done in army camps before we get the most satisfactory solution of the insect problem. Work of this kind must be taken up in advance of pressing needs or disaster may result. We must not wait, as many farmers have done, until the crop is nearly destroyed, before taking action. Life is too valuable, the stake too large to warrant this.

Mr. E. D. Ball: Dr. Felt's position is conservative. The man who has had actual field work in handling any insect pest is much better prepared to immediately take up the field end of the problem of insect control than any man approaching it from the medical, sanitation or engineering standpoint. The latter may be perfectly trained in their professions, but their knowledge of insects and their behavior is very limited. The great function of the entomologist should be to size up the situation in the ficld and devise suitable remedies to meet each condition that arises. The secret of the success of the American entomologist has been that he is resourceful in dealing with the problems that are placed before him. 
Mr. George A. Dean: The thing that surprises me most is the fact that so few of the medical men, bacteriologists, and sanitary engineers appreciate or even recognize that the entomologists can assist in solving these health problems. As Professor Lefroy of London, who visited my department only a few weeks ago, says, it is too bad, indeed, that we have to have terrible calamities come before we wake up and take notice. He says that at the present time there is Asiatic cholera and typhus right in the localities where many of our soldiers will be sent in France, and unless we are alive to the situation and expert entomologists are in the field, we are going to have the same sad experience that the English had in the first year of their campaign. Professor Lefroy was at loss to understand why this country, so well equipped with so many capable entomologists, was not using them in all of the army camps and units.

Secretary A. F. Burgess: I think we have had a very dangerous situation pointed out to us and that we appreciate that the situation is dangerous. We have also had pointed out that probably very little will be done until the situation becomes very serious indecd. I believe it is time for this Association to act. If we can do no more than go on record, we should do so, and point out what the situation is and that this Association and its members stand willing to assist in this great work. The difficulty of changing a system which already exists is very great, but unless all signs fail, the time is coming when it must be changed. It seems to me that the principle of the selective draft was to place men who were selected in positions for which they were best adapted. It is a pity that men who are trained along entomological lines and are needed should not be put on that important work. The time is coming when they will be, but I think the Association ought to consider this matter very carefully and take action at this meeting, pointing out the dangers that are ahead and placing its members at the service of the government.

Mr. Herbert Osborn: I feel very deeply on this subject and hesitate to express myself fully. I feel deeply because a great many young men have come to me and asked for advice. I could not tell them what to do. I knew that they were patriotic, and it seemed to me that they should serve their country where it would produce the greatest results for the government. Under existing agencies it is practically impossible for a man to go into the service as an entomologist. It is impossible for us to reorganize the agencies to bring about an order which would provide for entomologists as entomologists. I feel very strongly indeed that entomologists are American citizens. I think every one of our members in the United States wants to render the greatest service possible in this national emergency, and I think 
we may come to a point where we must do this through existing agencies. I still have hope that it may come through the selective draft,that men who put into their questionnaires a statement of their training will finally be assigned where they are best fitted to serve. I understand that certain groups of men have not been very cordially received because of their attempt to go into the army as a class. If the entomologists can get into the service, not as a class but as American citizens ready to go where they can be of the best service, they may ultimately be placed where they are able to do effective technical work. I do not wish to make any criticism that will give the idea that entomologists are not willing to serve their country in this time of nced. We are going into this matter with the utmost loyalty and we are ready to serve in any capacity that is really necessary. But I do believe our committec on resolutions could draft a carefully worded statement that there seems to be need of special service and that we have a specially trained body of men that might be of great value. It does scem a pity that the man who is thoroughly trained in entomological work and able to distinguish a fly, mosquito or other pest that is dangerous from one that is harmless-possibly save great expense or suffering and loss of life by exercising this knowledge-should not be placed where his knowledge may be of greatest value. I have two boys in the army, - one in the medical service and another, who is a trained entomologist, is in the infantry. Neither of them is able to do anything entomologically except as he may be able to offer suggestions to associates or superior officers. We ought to be very careful about making criticisms that may be misinterpreted, but we should make it plain that we are ready to do our utmost and that we wish to point out, if possible, lines along which the entomologist can assist in supporting the government agencies from a technical, scientific and entomological standpoint. Above all we want to help win this war.

Mr. E. P. FELT: I want to endorse most heartily what Professor Osborn has said. We are ready to give everything that we have and would like, if possible, to give along the most effective lines. If this Association, representing as it does the consensus of entomological opinion in the country, is willing to go on record as to the importance of this matter, I believe we will accomplish something. It isn't a question of preferment,--it is a question of rendering service. I believe that in our position as experts, we are justified in pointing out to those in charge of matters, the lines along which our men with their qualifications can work to the best advantage. That is what the government wants- to use the expert opinion of the country.

MR. S. J. Hunter: There is another phase of this matter which has come to my attention through conferences with students who have 
sought advice on this momentous subject. They will not go into this service that we all deem so important unless they can be made to feel in some official way that it is a real service that they are called upon to do for their country. I know of a number of cases of men who could have been assigned to entomological work but would not accept it as they preforred active military service, feeling that doing anything else was not fulfilling their entire patriotic duty to the country. It seems to me we ought to consider this matter.

Mr. T. J. Headlee: The War Department has commissioned two of our mosquito men as first lieutenants in the sanitary corp. One, Mr. Russell W. Gies, is now located at Camp Pike, Little Rock, Arkansas, and the other, Mr. Jesse B. Leslie, is stationed at Camp McClellan, Anniston, Alabama. They are engaged in mosquito work. I am convinced by a personal investigation of the situation at Washington, that the condition which prevents the utilization of the economic entomologist in the preservation of army health and comfort is a notion entertained by persons in charge of such matters, that he can contribute nothing worth while to that end. It appears to be the impression that the cconomic entomologist is a person interested primarily in the number of spots in the mosquito's wing or the number of spines upon the flea's foot and that his information is of a type that could not be put to practical use. Until this impression is removed and the true state of the case made clear, it is not to be expected that the economic entomologist will have a chance to do his professional bit in the army of the United States. The suggestion made by our Secretary is directly to the point. This Association should go on record in the form of a resolution or a set of resolutions in which the ability of the economic entomologist to perform a real scrvice in connection with the military establishment will be set forth. Further than this, it should provide a medium through which its action may be made clearly understood by the persons in charge of army sanitation and health.

Mr. W. C. O'Kane: It secms to me that we are surely united on two or three propositions. Professor Osborn has properly said that the first of all is the matter of service. As an association and as individual members we surely propose to do that which will be of greatest value so far as we are permitted to do so, whether it be in the infantry or in entomological work. Second, I am sure that we agree with Dr. Felt that the situation in regard to camps and tronches is serious. Third, I am sure we agree that the trained entomologist can render very genuine service. I am not sure that we shall get very far by depending upon the various local boards of review. I wish I did think so, but each of these boards is, in a sense, on the defensive. There are many men coming to them who wish to do special work, and some of 
these men wish to do it because they do not want to do something that might be more dangerous. That is not true of course of all men who go to them, but still it seems to me that the boards are on the defensive. Again there ought to be uniformity, so far as there is uniformity in the capabilities of entomologists. On the other hand, if we adopt resolutions here and print them in the Journal, I do not know just how much weight it will have. What I am wondering is whether, if the matter were rightly presented to the War Department by two or three men representing this Association,-not as a question of exemption or of preferred classification, but as a question of maximum service- -we might not get something out of it.

Mr. F. C. Bishop: I deeply appreciate the very careful analysis that Dr. Felt has given us of the situation. It certainly was a most admirable paper, and I also appreciate very heartily the comments of the various members of the Association and their effort to really put the entomologist in a position to do his greatest work in connection with the war situation. I have had a little personal experience in connection with the military camps, working largely in Texas where probably the greatest concentration of troops has been. I have come in contact more or less with the camps and regular army posts and have seen a little of the sanitary conditions. I can say that I fully agree with what Dr. Felt and others have said in regard to the need for the work of trained entomologists, and I also agree with the statements of Mr. O'Kane concerning the matter. At this time we must give very careful consideration to the interpretations that might be put upon an action of this sort, and this can best be done by a committee giving it very careful thought and then have the whole Association act following such a report.

President R. A. Cooley: I have been impressed with the loyalty of the young men in the colleges who have come up for military service, many of whom, while preferring service in their own line, were willing to serve in any capacity. Some that I know have attempted to withstand public sentiment, thinking that they could perform more valuable service in their own line than to enter the army or the navy. Another point which might be mentioned in connection with army work is the need for entomologists in the service outside of medical entomology. I believe Professor Lefroy, who was recently in this country, is not a medical entomologist at all, but was here on his way to investigate the work of certain insects on stored grains. Entomologists are needed in the army for the preservation of food stores as well as in medical or preventive work.

We have in Montana a State Board of Entomology. This was created by law for the purpose of studying the control of insects that 
transmit human and animal diseases. We have met with official barriers from the first in this work. I have no resentment in the matter at all and know just where the trouble is. It is merely because those high in authority do not see matters as we see them. I believe they think they are doing the very best they can, and I think it is highly desirable that there be a frank and full conference between representatives of this Association and certain men in Washington, and that very likely there will be no barrier between us at all.

Mr. F. C. BIsHop: I will say for the information of those here that my understanding in the case of Dr. Jennings is that his commission in the Sanitary Corps of the army was given not because he was an entomologist, but because he was a good all around sanitarian.

Mr. W. H. Goodwin: The point made by the English entomologists concerning the preservation of food products is of vital importance. Most people have no conception of the quantity rendered unfit for food by insect infestation. Most of the material voided by insects injurious to cereals and cereal products is in the form of ureates of ammonia, and contains practically no moisture. When these are taken into the digestive system they immediately become soluble, and cause an excess of ureates which may act as toxic poisons, and in small amounts daily cause a complexity of derangements. This has been tested experimentally in a limited way by feeding cakes made from infested material to dogs, and obtaining symptoms of toxic poisoning. We can draw our own conclusions concerning insect-contaminated products used for human food and its effects.

Mr. C. L. Metcalf: I am a little more hopeful about the situation than some of the members who have spoken. One of my former students is in the Base Hospital at Philadelphia. He told me several weeks ago that he was pretty certain that his captain was going to. utilize his services along insect lines. I am hopeful that our men going into service in the ordinary channels will be utilized by the War Department whether they are officially recognized as sanitary entomologists or not.

Mr. H. A. Gossard: I move that a special committee of three be appointed by the chair to consider a proper course of action and draft resolutions concerning this matter.

Secretary A. F. Burgess: I have a suggestion to make in this connection. At a good many of our meetings the committee on resolutions is rather an honorary job. It seems to me that if this matter were referred to them it would give them a chance to work to the limit. If the motion made has been seconded, I would like to offer an amendment that the matter be referred, in so far as resolutions are concerned, to the committee on resolutions. 
Mr. H. A. Gossard: I am just now told that already some steps have been taken by the committee on resolutions to try to meet the situation, so I will withdraw my motion.

By a vote of the Association, the matter was referred to the committee on resolutions.

Mr. E. D. BaLL: The committee on resolutions would request Professor Herbert Osborn and Dr. E. P. Felt to assist in the consideration of this matter and drawing of resolutions.

A motion was then made by the Secretary that a committee of three be appointed to bring any action which the Association might take through its committee on resolutions to the attention of the War Department or proper authorities in Washington. This matter was discussed freely by a number of members present, and after due consideration the Association voted that a committee of three be appointed by the President.

Adjournment.

Afternoon Session Tuesday, January 1, 1918, 1.30 p.m.

President R. A. Cooley: In view of the fact that none of the past presidents have arrived, I would suggest that the discussion of the subject "How Can the Entomologist Assist in Increasing Food Production?" be thrown open for discussion by the members.

Secretary A. F. Burgess: The state of Kansas has been doing a great deal of extension work, and at a good many of our meetings we have had reports from that state in connection with the successful work that has been done along that line. I don't like to embarrass any one, but I would like to ask Professor Dean if he won't open this discussion.

Mr. G. A. Dean: In view of the fact that insects cause in Kansas an annual loss of not less than $\$ 40,000,000$, and that fully $\$ 25,000,000$ of this amount could be eliminated if the practical methods of control that have been found effective were put into operation, your committee on insects hereby recommend to the committee on agricultural resources the following plans for doing effective work on insect control:

1. Organization of the 25 or more working entomologists of the state into a unit.

a. Office force

Publicity-newspaper articles and circulars

Correspondence

Planning and directing field work

b. Field force

Scouting work

Organization work

Demonstration work 
2. Apply the methods of control that are effective and practical to the farmer. This can be dono by carrying on a publicity campaign against the insects through farm papers, newspapers, farmers' institutes, granges, farmers' unions, county agents, etc.

3. Send out field men from time to time to kcep in touch with any threatening outbreaks and thus be prepared to put methods of control into operation at the most important time.

4. In case of threatening outbreaks, organize the counties for concerted action. These counties can be organized by townships, as thirteen counties were in 1913 for the control of grasshoppers, or by school districts, as more than twenty counties were in 1912 and 1913 for the control of chinch bugs. The counties may be organized through the county farm agents, as several have been for the control of Hessian fly.

5. Have the entomologists in the field to actually direct the field work, because many farmers will not apply the methods which they morely read, or, if they do, will often omit some important step in the work which is vital to its success.

6. Have the county committees furnish to the Committee on Insects the names and addresses of all township superintendents in order that, in case of any insect outbreak, they can assist in the organization of the community and permit us to render help with the least possible delay.

7. Prepare short, concise articles (little more than outline) on the life-history, habits and control measures for the more important injurious insects. Copies thereof should be furnished to members of the committee and to persons employed by it or coöperating with it. The articles can be assembled in bulletin form or left separate, as seems most desirable.

8. So unify and organize all the work over the state that the greatest amount of good can be accomplished with the least expenditure of labor and money.

Mr. M. H. Swenk: The problem, as it is stated here, "How Can the Entomologist Assist in Increasing Food Production?" seems to have two parts. One is, what has the entomologist to do; the other, how can he best do it?

Our President in his address stated that for the country as a whole we have an annual loss of 10 per cent of our crops. I believe this statement was first made by Mr. Marlatt in 1904, and other entomologists have repeated it. I had some doubts about the exactness of this percentage and took pains to verify it in this way: We have one file of economic letters for the past thirty years or more, and it is safe to assume, eliminating variations which may be due to publication of bulletins, that those letters would be a fair index as to insect injury. 
Especially for the past fifteen years we have analyzed these and submitted three years to very critical analysis. The three years were 1911, 1912 and 1913. The situation was analyzed carefully for each individual insect which seemed to enter into the destruction of crops that year; an average was taken and we found that for the cereal and forage crops the estimated loss ran pretty close to 10 per cent. In other words, for the state of Nebraska there was a loss of $\$ 15,000,000$ annually for cereal and forage crops for the past ten years. Mr. O'Kane has further pointed out that there is a great deal of variation in the amount of control which we can bring to bear upon the situation.

Professor Bruner and myself, in going over this problem, figured that a fair average for all cereal and forage crop pests, if the information we now have could be thoroughly and consistently applied, would be about 40 per cent. We have therefore the problem in our state of saving as much as possible of about $\$ 7,000,000$ worth of cereal and forage crops. That is the problem before us. As to how that can best be accomplished is the next question.

The first step it seems to me is for the entomologist to make an analysis of the situation as it occurs in his own state, to determine the pests which cause the most important losses in that state. This for the most part is a matter which would take only a short time, for the data is already at hand.

The next point is to conduct surveys and investigations and use all sources of information, to ascertain as far as possible the immediate conditions relating to those insects in the state and as far as possible to anticipate outbreaks of insect pests. This can be done in some cases; in other cases it is exceedingly difficult or impossible. As far as it can be done, however, it should be. The next point would be to employ :all extension forces of all sorts, looking toward the dissemination of information in advance, or at the time of the attack, which would have :a tendency to prevent or control those attacks. This may take the form of bulletins, it may take the form of personal conferences, of addresses before meetings, and perhaps other forms. It may even involve the completion of organizations destined to fight insects, the outbreaks of which can be anticipated. When the insect outbreak actually occurs, it seems to me that the placing of as large a force as possible in immediate point of infestation and the exertion of all energies possible toward the control of the outbreak is, of course, the proper thing to do.

Unsolved problems will, of course, arise. These, where they bear directly and importantly on the problem, should be given immediate and very serious attention.

The extension branch of entomology is one which in the last few 
months has grown vastly in importance, with the crisis upon us, and it is now in a formative stage. This, if ever, is the most desirable time to regulate as far as possible the form of organization.

The address of our President was exceedingly illuminative on this point, showing a great diversity in the form of organization. In any event, the organization should be such that the information should come from the entomology departments and they should be responsible for it.

In connection with the growth of this special research work, we should not neglect this because it is important; there is this possible danger: that we may overdevelop, perhaps, under the immediate pressing needs the extension aspect of our problem, and while developing our trackage and rolling stock, we may neglect the power house and find that eventually a discrepancy between the fund of information at hand and the extension of it.

Mr. H. A. Gossard: Since Professor Osborn has not yet arrived, I can state what we have done in Ohio the past season and indicate briefly the conditions under which we work. At present Ohio does not have a department of extension entomology, organized as such, but an effort is being made by the State University authorities to have one in operation the coming summer.

Early the past season, Dr. Herbert Osborn, who by common consent acts as a sort of honorary dean of the entomological forces of the state, invited the heads of the state entomological departments to meet at the University. We here attempted to coördinate a sort of program for extension work.

It so happens in Ohio that economic work has been centered at the Experiment Station and I was, therefore, charged with the special responsibility of executing the general program and carrying out the details according to my judgment as to what could best be done with the limited resources at our command. I was handicapped from the start because of losing two of my experienced men to a sister state, wise enough to pay them more money than I could obtain for them. At the same time a campaign for increased food production was inaugurated by the state executive departments acting conjointly with the extension forces of the State University, and the University authorities made us a visit one day and announced they had provided twenty or more men from the University staff to give body to the organization and that to complete it fifteen or twenty additional men from the station staff must be added to the force. While I was very dubious about the wisdom of reducing my staff any more, in consideration of the seeming emergency and to please those in charge of the state's executive machinery, I consented to release for a time my associate, $\mathrm{Mr}$. 
Houser, who had volunteered to take up this work if it was so desired by proper authority. He therefore was a district food commissioner in charge of two counties from April to July 1. The one remaining member of my staff was appointed military instructor in Wooster University and gave four afternoons per week to military instruction. My most dependable help were graduate student assistants in the University, one hundred miles away, whose services were placed at my disposal by Dr. Osborn, they voluntarily assenting to this arrangement.

So we started on a publicity campaign and a survey of entomological conditions, so far as our funds would permit. Fortunately, the publicity campaign had been pretty well shaped up and several of the articles written during the winter while we were yet at peace with the rest of the world.

In my office, each letter is subject-indexed when it is answered. The stenographer's duty is not ended with a letter until the species that happens to be the subject of inquiry has been entered in the indexbook in alphabetical order and a record made of the name of the writer, the date, and the locality from which the complaint came. We don't use the card system, it is too bulky, we use a loose-note system, each page having on it from 1 to 30 entries. We have in this way a record of every insect that has ever been a subject of complaint since the station was established. I can, therefore, tell in a few minutes if grasshoppers, Hessian flies or any other insect was present in the state in considerable numbers the preceding year or through any series of years. I can also tell at a glance from what localities they were reported. If I am not satisfied from a casual inspection of the record sheet, I can turn the record over to the clerk and ask that a map be made up from the record and in less than an hour I can have a map in hand which will show the localities from which a pest was reported the preceding year or through a series of preceding years. So I can tell about what to look for in a general way. I predicted in my early reports to Dr. Howard that we would have aphids and we did, but I was not able to specify that the potato aphid would be the conspicuous representative of this group. I was also able to indicate where the wheat-joint worm was located and to say there was little or no threat of Hessian fly or chinch bug. The Tussock caterpillar, canker-worms, curculio, potato beetle and a few others, developed exactly according to my forecast.

One of our first steps was to write to the county agents and district food commissioners, enclosing a list of manufacturers and dealers in insecticides and of makers and assemblers of spraying machinery and urge them to see that our press bulletins were given a place in their county papers; also to make sure there was a plentiful supply of insecticides and spraying materials available to their farmers. A ques- 
tionnaire was also sent them regarding the injurious insects most likely to be in sight.

Just before wheat harvest I got a sufficient working staff to make a state survey. With very limited funds, I had judged it to be unwise to dissipate them in aimless wandering about the state to see what might be loose, and, therefore, timed the work to give greatest belp to the crop of greatest importance during these war-times, viz., wheat. I believed the acreage could be increased if I could give the growers definite information that they were not seriously menaced by Hessian fly or other wheat insects and could safely do their seeding nearly at their own convenience. I, therefore, started four surveyors at four points on the southern border of the state and instructed them to proceed northward along four parallel lines, devoting approximately one day to each county. In laying out the routes, I paid some regard to the easiest lines of travel but aimed to make the stopping point in each county at a county seat, which was headquarters for a county agricultural agent or a county food commissioner. Then I wrote a letter to each of these county officials informing him of the purpose of the survey and requesting that he give such assistance as possible to the surveyors by way of transportation, information as to the location of the wheat districts, etc. I informed each that a day or two before my surveyor was due to arrive he would make his approach known by a long distance phone call or a night telegraph letter, and if said county officer could not be in his office the day of the surveyor's visit much assistance could be given by leaving a memorandum of the best route with the office clerk or that it might be possible to have arranged in advance a trip with some retired farmer willing and glad to loan the use of an automobile and acquainted with the wheat growers of the county. So far as I recall, every county agent visited personally responded to my request and gave most effective help to all the surveyors. One line of survey was made exclusively by automobile and this was undoubtedly the cheapest and most satisfactory means of transportation.

Each surveyor carried with him blank reports or questionnaires, one of which was filled out for each county and mailed to me or brought in by the surveyor. A hundred or more straws would be examined in each wheat field visited for Hessian fly and jointworm and the average of the day's examinations, supplemented by a general estimate, was taken as the average infestation of the county. Similar examinations were made for wheat midge and inquiries were made at every point for unusual entomological conditions. I gave a write-up of the survey in our September Monthly Bulletin which reaches about 50,000 Ohio farmers, published a rather full report of it in the Ohio Farmer, and by 
means of press bulletins scattered the information through the country newspapers. I wrote a personal letter to about four to six editors in each county, enclosing a copy of the press bulletin and urging them to print it if they had not already done so.

As I remember it, our State Secretary of Agriculture estimates that the wheat acreage of Ohio has been increased from 10 to 20 per cent over last year's acreage. It is of course impossible to tell how much of this result was due to our survey, which was part of a general propaganda engaged in by several state departments to increase the acreage. I sent questionnaires to all county agents not visited, so that we had fairly accurate knowledge regarding all parts of the state. Of our 88 counties, our surveyors personally investigated 56 .

We published fifteen or sixteen entomological articles, each from two to twelve or more pages in length, in our Monthly Bulletin, making these of a timely character. Part of these were written by the University staff. About 45 press bulletins were published. Our station editor keeps a careful record of how many papers make use of the press bulletins, and he reported to me that some of our bulletins were printed in 77 different papers and were adapted for use by two or three press bureaus. In no cases were the bulletins printed in fewer than from fifteen to twenty papers. We seemed to be getting all the publicity needful. Of course we could not determine very accurately how much of our advice was being used. In some counties, where we had the outbreak of potato aphid, the county agent would be coöperating with the horticultural department of the University, with private concerns like the Kentucky Tobacco Product Company, which had a skilled entomologist on the ground, and with us all at the same time. We only know the totals of such results. In one of our counties the saving was large as recorded in the Bulletin on the potato aphid recently distributed from our station.

Perhaps the methods we used are not the best that can be devised but they were the best we could think of to put into operation quickly under the circumstances previously detailed.

President R. A. Cooley: Professor Osborn has arrived and we will now be pleased to hear from him.

Mr. Herbert OsBorn: I believe we may all agree that this subject can properly be widened to cover both production and preservation of food. It goes without saying that we, as good Americans, will do everything in our power to support our government in the present crisis and will respond wherever duty may call. It is also evident that a particular phase of entomological work is offered in connection with army service for the medical and sanitary phases of work and in which it may be hoped our training may be utilized. The phase of 
work which is presented in this topic is perhaps of equal importance and, in this, entomological service is already recognized as of very great importance. It may be entered with hopefulness and assurance that results of value are being secured.

In this field the service of the economic entomologists may be dirccted along three or four distinct lines:

First, the pushing of investigations which bear most directly and urgently upon measures of protection and preservation of crops and which, it appears to me, should not be neglected during the stress of demands in fields which may for the moment seem more urgent. We may, I think, very properly, in view of the fact that many of our investigational members have been called into other lines of service, feel impelled to intensify our efforts and especially to concentrate efforts on essentials, leaving the unessential.

- Second, an extensive entomological survey, or field scouting plan, for the purpose of determining as accurately as possible the conditions of insect life, the most menacing species for the immediate future and the securing of data upon which we can make recommendations to cultivators in any part of the country or for the country at large. Such data may serve the purpose of determining what crops should be omitted or given particular care or for which special preventive or control measures will be advised at critical times. A special committee with this particular duty, to work in coöperation with the executive agencies, might be of special service.

Third, a very general distribution of information through various channels, the agricultural press, experiment station bulletins, etc., and particularly through extension agencies and county agents which come most directly in contact with the class of people necding assistance in insect control. The special effort here perhaps should be to unify the recommendations made through different agencies so as to avoid the discouraging confusion to the cultivator who is dealing with problems new to his experience.

Fourth, the instruction and training of entomological workers who will be greatly needed to fill the ranks that have been thinned by the calls to the other lines of service. Every entomological teacher should feel that he has a special duty at this time to help in this direction.

There is, it appears to me, a particular opportunity to demonstrate the value of the knowledge we possess concerning the control of insects since there is so general a demand for information from cultivators, especially those who have undertaken the cultivation of small tracts or gardens as a patriotic service. The effect of this on the future demand for entomological information will, I believe, prove to be one 
of the most epoch-making features of the entomological situation in connection with the present conditions.

We have, for many years, known a great number of useful control measures which it has been almost impossible to have adopted in a general way but which, once they can be shown to be profitable, will become a part of the general practice amongst fruit-growers, farmers and gardeners. The result, therefore, may be of permanent value as well as meeting a very urgent crisis at the present time.

It will be observed that these different phases of work are provided for in existing agencics, except perhaps for connected or carefully organized provision for the survey work.

President R. A. Cooley: We will be pleased to hear from Dr. Felt.

Mr. E. P. Felt: Especial stress, it seems to the speaker, should be laid upon the possibility of preventing apparently minor and comparatively insignificant losses throughout the country, since in the aggregate these count up tremendously, and in not a few instances the saving can be effected in an incidental manner and without an appreciable increase in cost for either insecticides or labor. These last will be more difficult to obtain in the future and, therefore, are important items in any plan to increase food production.

In this category we would place, possibly first of all, garden insects, especially in the case of small holdings, since here is a place where better control can be easily secured if there is only an understanding of the problems involved and the best methods of controlling the pests. It would simply be another step in making more efficient the millions of small gardeners throughout the country.

The care of stored grains and other food products is another instance along the same lines and if followed out systematically would prove an important aid in supplementing food deficiencies. This can be accomplished by well known methods, such as using up old stocks, the keeping of bins, barrels, granaries, etc., reasonably clean so there will be no centers for reinfestation and the exercise of a moderate degree of care to prevent introduction of infested material.

The adoption of every reasonable precautionary measure against insect attack is likely to be of great value and should be emphasized wherever possible; for example, in some sections of the country white grubs will be very destructive on recently turned sod land next season and the entomologist can render no better service than to make this knowledge generally available to those likely to be affected and thus save unnecessary destruction of susceptible crops, such as corn and potatoes. The efficacy of precautionary measures against such pests as the Hessian fly and the importance of promptly burning trimmings from orchards fall in the same category. 
The bearing rotation of crops may have upon insect injuries should be kept in mind and improvements suggested wherever it is possible to secure greater immunity from insect damage without, at the same time, causing loss or injury in other directions. An important point in this connection is that gencral practice in a locality has doubtless justificd itsclf by experience and one should consider the matter carefully before proposing innovations which in the long run may prove less successful. Preventive measures, as a rule, cost little and in these times of high prices and scarcity of help, expense and labor count for more than under normal conditions.

The value of good and clean culture cannot be too strongly emphasized, since we know that well cultivated crops will frequently outgrow insect injury that would be serious, if not fatal, to those receiving less care, and entomologists can cite numcrous cases where the lack of clcan culture has resulted in more or less damage, frequently serious, from insect pests. The origin of army worm outbreaks in thick weedy growths is one of the more striking instances, while the less serious damage by stalk borcrs and some of their allies is intimately related to an abundance of weeds.

Secondly, the entomologist should lay particular stress upon well recognized methods of controlling insects and urge activities along these lines. It is especially desirable that he should be in position, in case it is necessary, to restrict or modify spraying schedules, to indicate beyond question the applications which will give the maximum benefit at the minimum expenditure of time and money. It is particularly desirable that he limit his recommendations to methods which will surely result in benefit and preferably to those most likely to be effective in the hands of the average grower.

The present is an excellent time to question the efficacy of methods frequently recommended for the control of various insects and to ascertain whether in our enthusiasm for the theoretically perfect we may not have overstepped the line of the practical and advised treatments which in many instances would not justify themselves if a careful account was kept of profit and loss. Methods of problematical value may well be held in abeyance until further work has demonstrated their utility. There is a legitimate place for experimentation but for the present we believe, in case of large sized propositions, at least, that it is far better to advise a well-tried method, though it may be less efficient than will probably prove true of one which has not been thoroughly tested.

Now, supplementing that I would state that in New York last year we had an "Insect Pest Survey and Information Service." Through coöperation with county agents and special agents of the 
State Food Supply Commission, which was organized for the special purpose of promoting production, and the other scientific agencies such as the Experiment Stations, and Cornell University, etc., we endeavored to keep in close touch with conditions throughout the state and to distribute that information promptly, preferably through county agents, so that anybody in the state would know pretty nearly what was going on, entomologically spcaking. When possible wc endeavored to forecast and warn as to probable developments. Of course, that is a little bit dangerous. You can't tell whether you guess right or not, but it does seem wise to put the farmers and gardeners on their guard against possible developments, with the distinct idea that they are to watch and then go ahead. Another thing I think has been brought out rather emphatically in our experience during the past year is the great value of the local agent.

We have in our state a farm bureau agent for practically every county, and last summer, under the charge of Professor Crosby, we had entomologists working in important centers.

You gentlemen appreciate as well as $\mathrm{I}$, that it is surprising how many mistakes the average man can make without really trying, and we have found in hundreds of instances a man doing the wrong thing when he thought he was doing the right, and, of course, a concrete saving there means increased production. I believe, generally speaking, that we can accomplish more in conserving food supplies, etc., by emphasizing these comparatively insignificant features than we can by giving considerable attention to some larger and really more important matters. Save the small things and the larger ones will look out for themselves.

Mr. R. L. WeBster: Mr. President, it seems to me that this insect survey proposition is one of the most important points that has been brought out in the whole discussion. It leads us to information that we do not get in any other way. We do not get it through our correspondence because the farmers and fruit-growers do not see these things in time, and the college people do not get it because they are not in close touch. I think this is one of the most important things in the whole situation.

Mr. F. C. Bishopr: Mr. President, I think there is one aspect of this question that has not really been touched upon and that is the relation of insects affecting live stock in the production of the meat and food supply. We have a number of instances in which insects have materially cut down the production of the meat foods and the byproducts of them. This is a field which is being neglected in practice by the entomologists. It is being left a great deal to the veterinarians who unfortunately minimize the importance of these things. 
I might mention a few of the insects which should receive more attention at the hand of the entomologists both at the stations and in the extension work. For instance, in the case of the development of poultry industries, which have received a tremendous stimulus on account of the war conditions-many people are starting in poultry lines for the first time. They have no conception of the various difficulties they will meet. As a result they have lost much. This has been brought about by mites and lice. The ox-warble is responsible for a tremendous loss, lice of various kinds are also responsible for the cutting of growth, and of course, the ticks of various kinds are important.

I think as I said, that we should give a little more attention to this question, especially now that the nation is so hard pressed in the production of the meat and food products derived from animals.

Mr. J. J. Davis: We have had excellent results in our work in collaboration with the county agents. Our plan has been to carry on as much of our work as possible with the county agents. In this connection, when we first go into a county, we take up the entomological problems with the county agents; we learn from them and from personal observation what insects are important ones in that county and what insects are likely to be important ones. We then go over the whole matter with the county agent and make him thoroughly familiar with the different insects and the methods of control. We do this partly to save time for ourselves, because we cannot be in every county all the time. After we have discussed the matter in this way with the county agent so that he can handle it himself, it saves us a great deal of time.

Mr. T. J. HeadleE: In regard to the county agent problem, we find that the county agents have organized their counties into community organizations in most of the counties in the state. These community organizations are such that they cover the entire county and are sufficiently close together that when meetings are held at these places, it is only necessary to call the active farmers in the county. Through the development of the telephone service, it is now possible for a county agent to arrange a schedule within twenty-four hours if the need for it is known, and it is possible to get information promptly. The county agents with us have developed as executives-they have come to be the head of nearly all the agricultural organizations in the county. The result is that we have to appeal to the county executive to get things started.

It is perfectly practical to organize any movement necessary for the control of any insect. We know that is necessary. Our problem is one of scouting. We are scouting already for three species and we 
expect to scout for at least six or eight more before the next season opens. The scouting problem is a difficult one. The most discouraging thing about the efforts of the Department of Agriculture in the way of extension work, is that it is not providing apparently for this scouting work. Some of the men are trying to handle it under the head of survey work, but I am told that no provision had been made for scouting work and that if any is done it would have to be placed under the head of surveying. That is an unfortunate thing.

President R. A. Cooley: I might mention one or two matters in my own experience. We are all familiar with the fact that many county agents have had more or less entomological training and that they have in many cases come from widely separated states. It is a case of having a little knowledge in some instances, and there is a tendency, we have noticed, for them to make recommendations which might be widely at variance with recommendations which the home institution would make. We are, therefore, undertaking to furnish all county agents with a sheet dealing with an individual pest, briefly outlining the life-history, the recommendations that the state has adopted or we believe should adopt. Another point is mentioning at the bottom of the page a few important bulletins of the home state or of another state, the purpose of this being to make the work generally more effective and specifically to bring about uniformity in the state. These sheets may be recalled from time to time and new ones substituted as additional information is available.

We are hoping to make the work somewhat more effective by this method.

We are grateful to the Horticultural Section for allowing this infringement upon their time and I will now turn the meeting over to them.

Adjournment.

\section{The Section of Horticultural Inspection}

The sixteenth annual meeting of the Section on Horticultural Inspection was held in the Carnegie Museum at Pittsburgh, Pa., January 1,1918 , at 1.30 p. m. and 8.00 p. m.

The sessions were called to order by Prof. G. M. Bentley, Knoxville, Tenn., Chairman; with Prof. J. G. Sanders, Harrisburg, Pa., Secretary. The Federal Horticultural Board and committees of the American Association of Nurserymen, and of the Society of American Florists and Ornamental Horticulturists were invited to attend the sessions to discuss and confer on the proposed bill prohibiting the importation of nursery stock from foreign countries. One member of 